\title{
How to improve Thin Endometrium in Cases of Female Infertility
}

\author{
${ }^{1}$ Gangadhar Sahoo, ${ }^{2}$ Vishy Agrawal, ${ }^{3}$ Ruchika Garg, ${ }^{4}$ Neharika Malhotra
}

\begin{abstract}
Thin endometrium is frequently encountered during the treatment of female infertility. It is associated with lower implantation and pregnancy rates. Adequate growth is an integral step in endometrial receptivity and embryo implantation. Several modalities have been studied and include extended estrogen, pentoxifylline, tocopherol, low-dose aspirin, acupuncture, neuromuscular stimulation, L-arginine, vaginal sildenafil, granulocyte colonystimulating factor (G-CSF), and stem cell therapy. Studies show that vaginal sildenafil appears to be the first-line therapy option, G-CSF appears to be a potential second option, while stem cell therapy appears a new promising treatment modality.
\end{abstract}

Keywords: Endometrium thickness, Granulocyte colony-stimulating factor, Infertility, Stem cell therapy, Thin endometrium.

How to cite this article: Sahoo G, Agrawal V, Garg R, Malhotra N. How to improve Thin Endometrium in Cases of Female Infertility. J South Asian Feder Obst Gynae 2018;10(2):81-83.

Source of support: Nil

Conflict of interest: None

Date of received: 15 March 2018

Date of acceptance: 20 April 2018

Date of publication: July 2018

\section{INTRODUCTION}

Uterine causes of infertility contribute to about 5 to $10 \%$ of cases. A fairly normal uterine cavity and endometrial lining are necessary in order to conceive and maintain normal pregnancy. Gonen and Casper ${ }^{1}$ and Elnashar et $\mathrm{al}^{2}$ reported that thin endometrium less than $7 \mathrm{~mm}$ is considered as an important sign determining the implantation potential and it has a significant correlation

${ }^{1}$ Professor, ${ }^{2}$ Senior Resident, ${ }^{3}$ Associate Professor, ${ }^{4}$ Consultant

${ }^{1}$ Department of Obstetrics and Gynecology, IMS and SUM Hospital, Siksha 'O' Anusandhan Deemed University Bhubaneswar, Odisha, India

${ }^{2,3}$ Department of Obstetrics and Gynecology, Sarojini Naidu Medical College, Agra, Uttar Pradesh, India

${ }^{4}$ Department of Obstetrics and Gynecology, Rainbow IVF, Agra Uttar Pradesh, India

Corresponding Author: Vishy Agrawal, Senior Resident Department of Obstetrics and Gynaecology, Sarojini Naidu Medical College, Agra, Uttar Pradesh, India, e-mail: vishy 14agarwal@gmail.com with the duration of follicular stimulation and also with age.

Thin endometrium results due to

- Permanent damage to basal endometrium

- Resistance of endometrium surface receptors to estrogen

- Decreased blood flow to the endometrium

- Overexposure to testosterone

The endometrium is the special epithelial lining of the uterus above the level of internal os. It has two layers: a superficial functional and a deep basal layer. Miva et $\mathrm{al}^{3}$ found that the growth of the endometrium depends on the blood flow to the endometrial cavity and the angiogenesis and the thin endometrium is characterized by high-flow impedance of uterine radial artery, poor epithelial growth, and decreased expression of vascular endothelial growth factor resulting in thin endometrium.

\section{AGENTS USED TO INCREASE THE THICKNESS OF ENDOMETRIUM}

\section{Older Agents}

\section{Hormonal Adjustment}

Endometrial proliferation is dependent on serum estrogen levels, which results in progressive growth of the functional endometrium in the proliferative phase. Based on this, patients with thin endometrium were offered supplemental exogenous estrogen. Chen et $\mathrm{al}^{4}$ studied the role of estrogens in the development of endometrium. They had randomized patients with the endometrial thickness $<8 \mathrm{~mm}$ into two groups, and they found that the group which had received exogenous estrogen had a better development of endometrium than the group that did not.

\section{Pentoxifylline and Tocopherol}

Pentoxifylline (PTX) and tocopherol (vitamin E) combination had been found to improve endometrial thickness in patients with thin endometrium. ${ }^{5}$ Lédée-Bataille et $\mathrm{al}^{6}$ studied the role of PTX and tocopherol in combination for the development of endometrium and it was found that the patients who had received a dose of $400 \mathrm{mg}$ had a better development of endometrial lining (thickness was increased by $1.3 \pm 1 \mathrm{~mm}$ ). 
Acharya et $\mathrm{al}^{7}$ also studied the role of the combination and found that there were significant increases in the thickness of the endometrium at the end of treatment and also resulted in $40 \%$ pregnancy rate.

The mechanism of action of PTX resulting in better development of endometrium is that it causes vasodilation and also decreases inflammation.

\section{Low-dose Aspirin}

Studies have shown that patients receiving low-dose aspirin showed a better development of endometrium. ${ }^{8}$ There is significant increase in the endometrium thickness in the group receiving it than in the group which does not. ${ }^{9}$

The mechanism explaining the role of low-dose aspirin is that it decreases the pulsatility index of the uterine artery and thus increases the blood flow to the endometrium, resulting in a better growth.

\section{Acupuncture}

Acupuncture, one of the oldest interventions of traditional Chinese medicine, has been found to improve many gynecologic conditions including infertility. ${ }^{10,11}$

Stener-Victorin et $\mathrm{al}^{12}$ found that electroacupuncture decreases the uterine artery blood flow resistance and thus increases the blood flow. Ho et $\mathrm{al}^{13}$ in a randomized trial had also found that acupuncture results in a significant reduction in uterine artery impedance, resulting in increased blood flow and a better growth without a significant difference in pregnancy rates.

\section{L-Arginine}

L-arginine is a nitric oxide donor and relaxes vascular smooth muscles of endometrium as tried by Takasaki et al ${ }^{16}$ and it has been shown to decrease the resistive index.

\section{Nitroglycerine Patch}

It improves the uterine blood flow, but it is associated with side effects like headache and hypertension.

\section{Recent Agents}

\section{Vaginal Sildenafil}

It is a potent and selective inhibitor of cyclic guanosine monophosphate (cGMP)-specific phosphodiesterases that inhibit the breakdown of cGMP and potentiate the effect of nitric oxide on the vascular smooth muscle.

Sher and Fisch ${ }^{14}$ reported that the pulsatility index decreases after treatment with sildenafil, indicating increased diastolic blood flow after sildenafil administration.
Zinger et a 15 found that there is a significant increase in the endometrium thickness in two infertile patients with the thin endometrium receiving it. Takasaki et $\mathrm{al}^{16}$ found that vaginal sildenafil significantly increased the endometrium thickness from 7.1 to $9.4 \mathrm{~mm}(\mathrm{p}<0.01)$, with a $50 \%$ pregnancy rate after 12 in vitro fertilization (IVF) cycles.

\section{Granulocyte Colony-stimulating Factor}

Granulocyte colony-stimulating factor is described as a hematopoietic growth factor that has currently been shown to have important functions in nonhematopoietic cells, such as the endometrium. ${ }^{17}$

Lucena and Moreno-Ortiz ${ }^{18}$ reported that a patient with thin endometrium $(<5.7 \mathrm{~mm})$ during an in vitro maturation cycle who was given $300 \mu \mathrm{g}$ of G-CSF on the day of oocyte retrieval showed a significant growth in endometrium.

Recently, Barad et $\mathrm{al}^{19}$ tried to increase the use of G-CSF for increasing the endometrial thickness in all patients undergoing IVF or frozen embryo transfer, regardless of endometrial thickness.

\section{Stem Cell Therapy}

Studies have supported the presence of progenitor cells in the endometrium and these cells proved to have a high regenerative capacity. ${ }^{20-23}$

Cervello et $\mathrm{al}^{24}$ demonstrated that endometrial stem cells are able to generate human endometrium after transplantation in mice renal capsules.

Taylor ${ }^{25}$ also demonstrated the role of endometrial progenitor cells in the development of endometrium.

\section{Endometrial Scratch}

A few randomized controlled trials have shown that endometrial scratching in the luteal phase of one cycle prior to IVF cycle increases the endometrial thickness and pregnancy rate. The rationale of using endometrial cratch is based on the fact that the tissue injury procedures such as endometrial biopsy induces stem cell differentiation and increases endometrial receptivity.

\section{Platelet-rich Plasma}

It has been shown to be useful in cases of thin endometrium as well as in cases of implantation failure.

\section{CONCLUSION}

Receptive endometrium with proper endometrial development plays an important role in embryo implantation. Among multiple available treatment options, vaginal sildenafil during the stimulation cycle appears to be a reasonable first-line treatment option. Stem cell therapy 
appears to have a great role in the refractory cases; however, more research regarding safety, effectiveness, and cost is required.

\section{REFERENCES}

1. Gonen Y, Casper RF. Prediction of implantation by sonographic appearance of the endometrium during controlled ovarian stimulation for in vitro fertilization (IVF). J In Vitro Fert Embryo Transf 1990 Jun;7(3):146-152.

2. Elnashar A, Afifi A, Donia D. Endometrial thickness and pregnancy rates in infertile couple undergoing AIH. Behna M J 1995;12:1-9.

3. Miwa I, Tamura H, Takasaki A, Yamagata Y, Shimamura K, Sungio N. Pathophysiology features of "thin endometrium". Fertil Steril 2009;91:998-1004.

4. Chen MJ, Yang JH, Peng FH, Chen SU, Ho HN, Yang YS. Extended estrogen administration for women with thin endometrium in frozen-thawed in-vitro fertilization programs. J Assist Reprod Genet 2006 Jul-Aug;23(7-8):337-342.

5. Chiao TB, Lee AJ. Role of pentoxifylline and vitamin $E$ in attenuation of radiation-induced fibrosis. Ann Pharmacother 2005 Apr;39(3):516-522.

6. Lédée-Bataille N, Olivennes F, Lefaix JL, ChaouatG, Frydman R, Delanian S. Combined treatment by pentoxifylline and tocopherol for recipient women with a thin endometrium enrolled in an oocyte donation programme. Hum Reprod 2002 May;17(5):1249-1253.

7. Acharya S, Yasmin E, Balen AH. The use of a combination of pentoxifylline and tocopherol in women with a thin endometrium undergoing assisted conception therapies-a report of 20 cases. Hum Fertil (Camb) 2009 Dec;12(4):198-203.

8. Wada I, Hsu CC, Williams G, Macnamee MC, Brinsden PR. The benefits of low-dose aspirin therapy in women with impaired uterine perfusion during assisted conception. Hum Reprod 1994 Oct;9(10):1954-1957.

9. Hsieh YY, Tsai HD, Chang CC, Lo HY, Chen CL. Low-dose aspirin for infertile women with thin endometrium receiving intrauterine insemination: a prospective, randomized study. J Assist Reprod Genet 2000 Mar;17(3):174-177.

10. Paulus WE, Zhang M, Strehler E, El-Danasouri I, Sterzik K. Influence of acupuncture on the pregnancy rate in patients who undergo assisted reproduction therapy. Fertil Steril 2002 Apr;77(4):721-724.

11. Westergaard LG, Mao Q, Krogslund M, Sandrini S, Lenz S, Grinsted J. Acupuncture on the day of embryo transfer significantly improves the reproductive outcome in infertile women: a prospective, randomized trial. Fertil Steril 2006 May;85(5):1341-1346.
12. Stener-Victorin $\mathrm{E}$, Waldenstrom $\mathrm{U}$, Andersson SA, Wikland M. Reduction of blood flow impedance in the uterine arteries of infertile women with electro-acupuncture. Hum Reprod 1996 Jun;11(6):1314-1317.

13. Ho M, Huang LC, Chang YY, Chen HY, Chang WC, Yang TC, Tsai HD. Electroacupuncture reduces uterine artery blood flow impedance in infertile women. Taiwan J Obstet Gynecol 2009 Jun;48(2):148-151.

14. Sher G, Fisch JD. Vaginal sildenafil (Viagra): a preliminary report of a novel method to improve uterine artery blood flow and endometrial development in patients undergoing IVF. Hum Reprod 2000 May;15(4):806-809.

15. Zinger M, Liu JH, Thomas MA. Successful use of vaginal sildenafil citrate in two infertility patients with Asherman's syndrome. J Womens Health (Larchmt) 2006 May;15(4):442-444.

16. Takasaki A, Tamura H, Miwa I, Taketani T, Shimamura K, Sugino N. Endometrial growth and uterine blood flow: a pilot study for improving endometrial thickness in patients with a thin endometrium. Fertil Steril 2010 Apr;93(6):1851-1858.

17. Jensen JR, Witz CA, Schenken RS, Tekmal RR. A potential role for colony-stimulating factor 1 in the genesis of the early endometriotic lesion. Fertil Steril 2010 Jan;93(1):251-256.

18. Lucena E, Moreno-Ortiz H. Granulocyte colony-stimulating factor (G-CSF): a mediator in endometrial receptivity for a patient with polycystic ovary (PCO) undergoing in vitro maturation (IVM). BMJ Case Rep 2013 Apr;2013:008115.

19. Barad DH, Yu Y, Kushnir VA, Shohat-Tal A, Lazzaroni E, Lee HJ, Gleicher N. A randomized clinical trial of endometrial perfusion with granulocyte colony-stimulating factor in in vitro fertilization cycles: impact on endometrial thickness and clinical pregnancy rates. Fertil Steril 2014 Mar;101(3):710-715.

20. Padykula HA, Coles LG, McCrackenJA, King NW Jr, LoncopeC, Kaiserman-Abramof IR. A zonal pattern of cell proliferation and differentiation in the rhesus endometrium during the estrogen surge. Biol Reprod 1984 Dec;31(5):1103-1118.

21. PadykulaHA,ColesLG,OkuliczWC,RapaportSI,McCrackenJA, King NW Jr, Longcope C, Kaiserman-Abramof IR. The basalis of the primate endometrium: a bifunctional germinal compartment. Biol Reprod 1989 Mar;40(3):681-690.

22. Gargett CE. Uterine stem cells: what is the evidence? Hum Reprod Update 2007 Jan-Feb;13(1):87-101.

23. Gargett CE, Nguyen HP, Ye L. Endometrial regeneration and endometrial stem/progenitor cells. Rev Endocr Metab Disord 2012 Dec;13(4):235-251.

24. Cervello I, Mas A, Gil-Sanchis C, Peris L, Saunders PT, Critchley HO, Simón C. Reconstruction of endometrium from human endometrial side population cell lines. PLoS One 2011 Jun;6(6):e21221.

25. Taylor HS. Endometrial cells derived from donor stem cells in bone marrow transplant recipients. JAMA 2004 Jul;292(1):81-85. 